\title{
PENGARUH SISTEM OLAH TANAH DAN PEMUPUKAN NITROGEN JANGKA PANJANG TERHADAP JUMLAH SPORA MIKORIZA VESIKULAR ARBUSKULAR DAN INFEKSI AKAR TANAMAN PADI GOGO VARIETAS INPAGO-8 PADA MUSIM TANAM KE-46
}

\author{
Lilis Ratnawati, Sri Yusnaini, Muhajir Utomo \& Ainin Niswati \\ Jurusan Agroteknologi Fakultas Pertanian Universitas Lampung \\ J1. Sumantri Brojonegoro No 1 Bandar Lampung 35143 \\ E-mail: Lilisratnawati35@gmail.com
}

\begin{abstract}
ABSTRAK
Mikoriza vesikular arbuskular (MVA) merupakan fungi yang mampu bersimbiosis mutualisme dengan akar tanaman. Keberadaan MVA di dalam tanah dipengaruhi oleh beberapa kegiatan pertanian seperti pengolahan tanah dan pemupukan. Tujuan dari penelitian ini adalah untuk mempelajari pengaruh sistem pengolahan tanah terhadap jumlah spora MVA dan infeksi akar tanaman padi gogo, mempelajari pengaruh aplikasi pupuk $\mathrm{N}$ terhadap jumlah spora MVA dan infeksi akar tanaman padi gogo, mempelajari pengaruh interaksi antara sistem olah tanah dan aplikasi pupuk $\mathrm{N}$ terbaik terhadap jumlah spora MVA dan infeksi akar tanaman padi gogo, dan mempelajari korelasi antara beberapa variabel pertumbuhan tanaman dan sifat-sifat tanah dengan jumlah spora MVA dan infeksi akar tanaman padi gogo. Penelitian ini menggunakan rancangan acak kelompok (RAK), yang disusun secara faktorial $(2 \times 3)$, dengan 4 ulangan. Faktor pertama adalah olah tanah intensif $\left(\mathrm{T}_{1}\right)$, olah tanah minimum $\left(\mathrm{T}_{2}\right)$ dan tanpa olah tanah $\left(\mathrm{T}_{3}\right)$; dan faktor kedua adalah tanpa pupuk $\mathrm{N}\left(\mathrm{N}_{0}\right)$ dan pemberian pupuk $100 \mathrm{~kg} \mathrm{~N}^{-1}\left(\mathrm{~N}_{1}\right)$. Homogenitas ragam diuji dengan uji Bartlet dan Additifitas ragam dengan uji Tukey. Data yang diperoleh, dianalisis ragam dan dilanjutkan dengan menggunakan uji beda nyata terkecil (BNT) pada taraf 5\%. Uji korelasi dilakukan terhadap variabel utama dan variabel pendukung. Hasil penelitian menunjukkan bahwa perlakuan $\mathrm{T}_{2}$ dan $\mathrm{T}_{3}$ memiliki persen infeksi akar lebih tinggi dibandingkan dengan $\mathrm{T}_{1}$. Perlakuan $\mathrm{N}_{0}$ memiliki jumlah spora MVA lebih tinggi dibandingkan dengan pemberian pupuk $\mathrm{N}_{1}$, serta tidak terjadi interaksi antara sistem olah tanah dengan pemupukan $\mathrm{N}$ terhadap jumlah spora MVA dan persen infeksi akar. Tidak terjadi korelasi antara jumlah spora MVA dan persen infeksi akar dengan variabel pendukung, kecuali kadar air tanah yang memiliki berkorelasi positif dengan persen infeksi akar.
\end{abstract}

Kata kunci: mikoriza vesikular arbuskular, pemupukan N, sistem olah tanah

\section{PENDAHULUAN}

Padi merupakan tanaman penghasil beras yang dikonsumsi oleh sebagian besar masyarakat Indonesia. Namun produksi padi masih rendah sehingga belum mencukupi kebutuhan masyarakat Indonesia. Rendahnya produksi tersebut diperkirakan terjadi karena penurunan luas panen. Menurunnya luas panen disebabkan oleh alih fungsi lahan dan produktivitas lahan yang semakin menurun. Oleh karena itu, perlu adanya pemanfaatan lahan kering di Indonesia untuk dijadikan alternatif budidaya tanaman padi. Namun permasalahan pada lahan kering yaitu mudah terdegradasi menjadi lahan kritis. Menurut Utomo (2012), Penyebab utama degradasi lahan adalah erosi oleh air dan emisi karbon, pencucian hara, dan penurunan kadar bahan organik tanah. Upaya untuk meningkatkan produksi padi gogo pada lahan kering di Indonesia salah satunya dengan intensifikasi lahan. Intensifikasi lahan merupakan upaya peningkatan produksi pertanian tanpa menambah luas lahan yang ada, tetapi mengupayakan lahan seoptimal mungkin caranya yaitu dengan pengolahan tanah dan pemupukan.

Pengolahan tanah merupakan kegiatan persiapan lahan untuk budidaya tanaman. Menurut Utomo (2012), olah tanah intensif merupakan sistem olah tanah yang dilakukan sebanyak dua kali untuk menggemburkan tanah agar akar tanaman dapat tumbuh dengan baik serta permukaan tanah yang bersih tanpa ada gulma. Olah tanah minimum dilakukan dengan mengoret gulma yang ada di permukaan tanah tanpa mengolah tanah secara intensif dan tanpa olah tanah dilakukan dengan dengan membuat lubang tugalan untuk menempatkan benih.

Pemupukan merupakan salah satu kegiatan yang dilakukan untuk menambah unsur hara ke dalam tanah agar dapat dimanfaatkan oleh tanaman untuk meningkatkan pertumbuhan dan hasil tanaman serta sumber energi bagi mikroorganisme tanah. Menurut 
Marsono (2001), unsur hara nitrogen merupakan salah satu unsur hara penting untuk untuk merangsang pertumbuhan secara keseluruhan, khususnya batang, cabang dan daun serta berperan penting dalam pembentukan hijau daun yang sangat berguna dalam proses fotosintesis dan membentuk protein, lemak dan berbagai persenyawaan organik lainnya.

Kegiatan pertanian seperti pengolahan lahan dan pemupukan akan berdampak pada keberadaan dan keanekaragaman mikroorganisme tanah. MVA merupakan simbiosis antara fungi dengan akar tanaman. Akar tanaman yang terinfeksi oleh MVA akan membantu akar dalam penyerapan hara dan air di dalam tanah dengan cara memperluas bidang serapan akar dengan adanya hifa eksternal yang tumbuh dan berkembang melalui bulu akar. MVA selain dapat meningkatkan serapan hara, juga dapat meningkatkan ketahanan tanaman terhadap penyakit terbawa tanah, meningkatkan toleransi tanaman terhadap kekeringan, menstabilkan agregat tanah, dan sebagainya (Simanungkalit dkk., 2006). Tetapi, penggunaan sistem olah tanah dan pemupukan mampu mempengaruhi perkecambahan spora MVA dan infeksi akar tanaman padi gogo. Hal ini berkaitan dengan faktor lingkungan dan perubahan beberapa sifat-sifat tanah akibat dari penggunaan sistem olah tanah dan pemupukan. Untuk itu perlu dilakukan penelitian tentang pengaruh sistem olah tanah dan pemupukan terhadap jumlah spora MVA dan infeksi akar MVA pada tanaman padi gogo.

\section{BAHAN DAN METODE}

Penelitian ini dilaksanakan pada bulan November 2014 - Mei 2015. Di Kebun Percobaan Politeknik Negeri Lampung dan di Laboratorium Bioteknologi Fakultas Pertanian, Universitas Lampung.

Alat yang digunakan adalah gelas beaker, saringan $600 \mu \mathrm{m}, 212 \mu \mathrm{m}$ dan $45 \mu \mathrm{m}$, cawan petri, pinset, timbangan, termometer, gunting, gelas objek, water bath, cover gelas, dan mikroskop. Bahan yang digunakan adalah sampel tanah dan akar tanaman padi gogo, larutan $\mathrm{KOH} 10 \%, \mathrm{HCl} 2 \%$, gliserin 86\%, Triphan Blue, plastik, aquades, label, tissue, kamera dan alat tulis.

Penelitian ini dilakukan menggunakan Rancangan Acak Kelompok (RAK) yang disususn secara faktorial (3x2) dengan 4 ulangan. Faktor pertama adalah perlakuan sistem olah tanah $(\mathrm{T})$ yaitu $\mathrm{T}_{1}=$ olah tanah intensif, $\mathrm{T}_{2}=$ olah tanah minimum dan $\mathrm{T}_{3}=$ tanpa olah tanah. Sedangkan faktor kedua adalah perlakuan pemupukan nitrogen (N) yaitu $\mathrm{N}_{0}=0 \mathrm{~kg} \mathrm{~N} \mathrm{ha}^{-1}$ dan $\mathrm{N}_{1}=100 \mathrm{~kg} \mathrm{~N}$ $\mathrm{ha}^{-1}$. Data hasil pengamatan diuji homogenitas ragamnya dengan uji Bartlett dan additivitasnya diuji dengan uji
Tukey, selanjutnya uji dianalalisis menggunakan analisis ragam. Jika perlakuan yang diterapkan memberikan pengaruh nyata maka dilanjutkan dengan Uji Beda Nyata Terkecil (BNT) pada taraf 5\%. Uji korelasi dilakukan untuk mengetahui hubungan antara variabel utama dengan variabel pendukung.

Penelitian ini merupakan penelitian jangka panjang yang dimulai sejak tahun 1987 dan saat ini memasuki musim tanam ke-46 tahun ke-28 dengan penerapan sistem olah tanah konservasi dan pola pergiliran tanaman serealia (jagung/padi gogo) - legum - bera. Pengambilan sampel dilakukan dua kali yaitu sebelum olah tanah (Sebelum Perlakuan) dan saat tanaman memasuki fase vegetatif maksimum. Pengambilan sampel pertama dilakukan secara komposit dengan menggunakan bor tanah sedalam $0-20 \mathrm{~cm}$. Sedangkan pengambilan sampel kedua pada saat tanaman memasuki fase vegetatif maksimum dengan cara membongkar tanaman kemudian di pisahkan akar dengan tanaman dan diambil sampel tanah di sekitar perakaran tanaman.

Persiapan lahan yang terdiri dari 24 petak dengan luasan petak yaitu $4 \mathrm{~m}$ x $6 \mathrm{~m}$ dengan jarak antar petak $0,5 \mathrm{~m}$. Sebelum dilakukan penanaman dilakukan pengolahan tanah (Sesuai Perlakuan). Sebelum dilakukan pengolahan tanah maka untuk mengendalikan gulma yang ada di lahan penelitian maka dilakukan penyemprotan dengan menggunakan campuran herbisida Rhodiamine dengan dosis 1,0 $\mathrm{L} \mathrm{ha}^{-1}$ (Bahan Aktif 2,4-D Dimetil Amina) dan Roundup dengan dosis 6,0 $\mathrm{L} \mathrm{ha}^{-1}$ (Bahan Aktif Glifosat.). Setelah disemprot, petak lahan pada $\mathrm{T}_{1}$ dibersihkan dari serasah tanaman dan gulma, kemudian lahan tersebut diolah dua kali sedalam 0-20 $\mathrm{cm}$. Petak lahan pada $\mathrm{T}_{2}$ semua serasah dan gulma dikored dan dikembalikan ke lahan penelitian sebagai mulsa, sedangkan pada petak $\mathrm{T}_{3}$ lahan tidak dikoret, tetapi semua serasah tanaman dan gulma yang mati langsung digunakan sebagai mulsa (Utomo, 2012). Setelah itu penanaman dilakukan secara tugal degan jarak $25 \mathrm{~cm} \times 20 \mathrm{~cm}$. Benih yang digunakan adalah benih padi gogo varietas Inpago-8.

Pemupukan dilakukan pada saat padi gogo berumur 1 MST, pupuk yang diberikan yakni Urea dengan dosis $0 \mathrm{~kg} \mathrm{~N}^{-1}$ dan $100 \mathrm{~kg} \mathrm{~N}^{-1}$ (Sesuai Perlakuan), SP-36 dengan dosis $150 \mathrm{~kg} \mathrm{ha}^{-1}$, dan $\mathrm{KCl}$ dengan dosis $100 \mathrm{~kg} \mathrm{ha}^{-1}$. Pupuk Urea diberikan dua kali yaitu 1/3 dosis pada saat padi gogo berumur satu minggu dan sisanya pada saat satu bulan setelah tanam. Pemupukan dilakukan dengan cara dilarik di sisi barisan tanaman padi gogo. Pemeliharaan meliputi penyiraman, pengendalian OPT (Organisme Penganggu Tanaman), pengendalian gulma dilakukan secara manual dan penyulaman. 
Variabel pengamatan penelitian ini adalah :

1. Jumlah spora mikoriza vesikular arbuskular (100 g $\left.\tan \mathrm{h}^{-1}\right)$. Pengamatan dilakukan dengan menggunakan metode penyaringan basah. Ditimbang $100 \mathrm{~g}$ sampel tanah dan dimasukkan ke dalam gelas beaker, diaduk. Setelah itu diberi air $500 \mathrm{ml}$, dicampur rata, lalu didiamkan selama 10 menit sampai partikelpartikel mengendap. Selanjutnya larutan dituang ke dalam saringan bertingkat berukuran $600 \mu \mathrm{m}$ dan filtratnya di tampung digelas beaker. Kemudian suspensi tanah dibersihkan dan dicuci kembali pada air mengalir kemudian lewatkan pada saringan 212 $\mu \mathrm{m}$ dan $45 \mu \mathrm{m}$ sampai filtratnya bening. Dalam proses pencucian dapat dilakukan berulang-ulang sampai partikel tanah bersih dari fraksi liat. Setelah itu suspensi tanah dipindahkan ke cawan petri kemudian diamati spora di bawah mikroskop dan dihitung jumlah spora MVA(Yusnaini dkk., 2012).

2. Infeksi akar MVA pada tanaman padi gogo (\%). Pengamatan infeksi akar dilakukan dengan cara sampel akar tanaman padi gogo dicuci. Kemudian diletakkan dalam cawan petri berisi air dan dipotongpotong dengan panjang $1 \mathrm{~cm}$. Selanjutnya potongan akar direndam dalam larutan $\mathrm{KOH} \mathrm{10 \%} \mathrm{kemudian}$ dimasukkan ke dalam water bath, dipanaskan sampai suhu $90^{\circ} \mathrm{C}$ selama 10-15 menit. Setelah itu, direndam dengan larutan $\mathrm{HCl} 2 \%$ selama 2 menit kemudian bilas dengan aquades beberapa kali. Selanjutnya akar direndam dalam tryphan blue pada suhu $90^{\circ} \mathrm{C}$ selama 10-15 menit. Setelah itu, direndam dalam larutan gliserin $50 \%$ selama 24 jam. Kemudian potongan akar disusun dalam gelas objek, sebanyak 10 potong akar dan gelas objek tersebut ditutup dengan cover gelas. Pengamatan dilakukan dengan menggunakan mikroskop perbesaran 40-400 x dan dihitung persentase infeksi akar dengan rumus (Yusnaini dkk., 2012):

$$
\% \text { infeksiakar }=\frac{\sum \text { contoh akar terinfeksi }}{\sum \text { contohakar }} \times 100 \%
$$

Variabel pendukung yang diamati sebelum perlakuan olah tanah dan pada saat fase vegetatif maksimum yaitu: Suhu tanah $\left({ }^{\circ} \mathrm{C}\right)$, Kadar air tanah $(\%), \mathrm{pH}$ tanah, C-organik tanah (\%), N-total tanah (\%), P-tersedia tanah (ppm), Ratio C/N tanah (\%), Bobot berangkasan kering tanaman (g) dan Bobot kering akar (g).

\section{HASIL DAN PEMBAHASAN}

Pengamatan pada Sebelum Olah Tanah. Hasil pengamatan jumlah spora MVA menujukkan bahwa jumlah spora tertinggi terdapat pada perlakuan $\mathrm{N}_{0} \mathrm{~T}_{2}$ yaitu sebanyak 252 spora dalam $100 \mathrm{~g} \mathrm{tanah}^{-1}$ dan jumlah spora MVA terendah pada perlakuan $\mathrm{N}_{1} \mathrm{~T}_{3}$ yaitu sebanyak 103 spora dalam $100 \mathrm{~g} \operatorname{tanah}^{-1}$ (Tabel 1). Pada penelitian ini ditemukan 2 jenis spora MVA yaitu spora 1 dengan warna putih berbentuk bulat dan spora 2 dengan warna coklat transparan berbentuk bulat (Gambar 1A dan 1B).

Pengamatan pada Fase Vegetatif Maksimum. Hasil pengamatan menunjukkan bahwa jumlah spora tertinggi terdapat pada perlakuan $\mathrm{N}_{0} \mathrm{~T}_{2}$ yaitu sebanyak 250 spora dalam $100 \mathrm{~g}$ tanah $^{-1}$ dan jumlah spora MVA terendah pada perlakuan $\mathrm{N}_{1} \mathrm{~T}_{3}$ yaitu sebanyak 204 spora dalam $100 \mathrm{~g} \mathrm{tanah}^{-1}$ (Tabel2). Hasil uji BNTmenunjukkan bahwa jumlah spora pada perlakuan sistem olah tanah tidak berbeda nyata, sedangkan pada perlakuan pupuk $\mathrm{N}$ berbeda nyata. Pada perlakuan tanpa pupuk $\mathrm{N}$ jumlah spora MVA lebih tinggi dibandingkan dengan perlakuan pupuk N (Tabel 3). Hal ini diduga karena pada penambahan pupuk $\mathrm{N}$ akan terjadi proses dekomposisi bahan organik sehingga akan berlangsung proses nitrifikasi.

Pada kondisi yang tidak menguntungkan kemungkinan akan terjadi penimbunan nitrit maupun nitrat. Adanya nitrit dan nitrat dalam jumlah yang tinggi tidak menguntungkan untuk pertumbuhan tanaman dan mikroorganisme tanah salah satunya yaitu MVA karena nitrit bersifat racun (Hakim dkk., 1986). Sedangkan, pada kondisi perlakuan tanpa pupuk $\mathrm{N}$ diduga MVA dapat
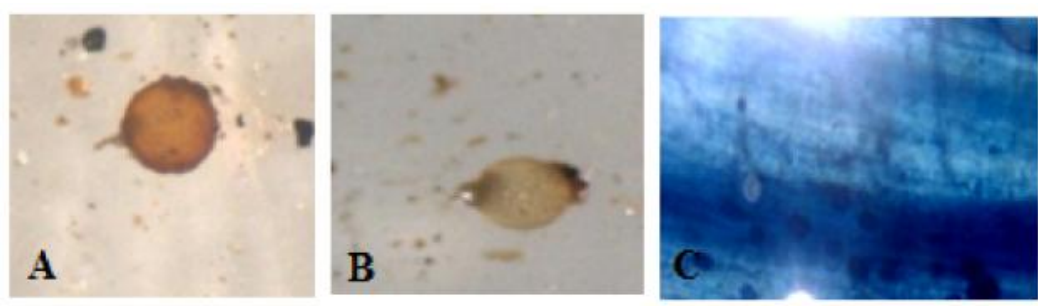

Gambar 1. Spora MVA yang ditemukan di pertanaman padi gogo A : Spora 1 berbentuk bulat berwarna coklat, B: Spora 2 berbentuk bulat, berwarna putih bening, $C$ : Vesikel didalam jaringan akar yang terinfeksi MVA pada pertanaman padi gogo. 
Tabel 1. Spora mikoriza vesikular arbuskular (MVA) pada lahan penelitian sebelum olah tanah (Awal)

\begin{tabular}{|c|c|c|c|c|c|c|c|}
\hline \multirow{4}{*}{ Perlakuan } & \multicolumn{6}{|c|}{ Lolos Saringan } & \multirow{4}{*}{$\begin{array}{l}\text { Spora } \\
\text { MVA }\end{array}$} \\
\hline & \multicolumn{2}{|c|}{$600 \mu \mathrm{m}$} & \multicolumn{2}{|c|}{$212 \mu \mathrm{m}$} & \multicolumn{2}{|c|}{$45 \mu \mathrm{m}$} & \\
\hline & \multicolumn{6}{|c|}{ Warna } & \\
\hline & Coklat & Putih & Coklat & Putih & Coklat & Putih & \\
\hline \multicolumn{8}{|c|}{ 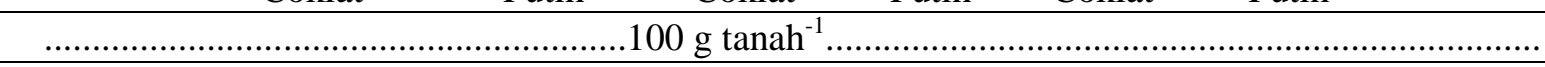 } \\
\hline $\mathrm{N}_{0} \mathrm{~T}_{1}$ & 1 & - & 14 & 4 & 113 & 29 & 161 \\
\hline $\mathrm{N}_{1} \mathrm{~T}_{1}$ & - & - & 5 & 13 & 147 & 86 & 251 \\
\hline $\mathrm{N}_{0} \mathrm{~T}_{2}$ & 2 & - & 4 & 2 & 164 & 80 & 252 \\
\hline $\mathrm{N}_{1} \mathrm{~T}_{2}$ & - & - & 4 & 7 & 52 & 59 & 122 \\
\hline $\mathrm{N}_{0} \mathrm{~T}_{3}$ & - & - & 9 & 6 & 128 & 94 & 237 \\
\hline $\mathrm{N}_{1} \mathrm{~T}_{3}$ & - & - & 8 & 3 & 53 & 39 & 103 \\
\hline
\end{tabular}

Keterangan : $\mathrm{T}_{1}=$ Olah Tanah Intensif, $\mathrm{T}_{2}=$ Olah Tanah Minimum, $\mathrm{T}_{3}=$ Tanpa Olah Tanah, $\mathrm{N}_{0}=$ Tanpa Pupuk N, $\mathrm{N}_{1}=$ Pupuk N $100 \mathrm{~kg} \mathrm{~N} \mathrm{ha}^{-1}$. Sampel tanah diabil secara komposit dengan 6 perlakuan.

Tabel 2. Spora MVA pada fase vegetatif maksimum tanaman padi gogo

\begin{tabular}{|c|c|c|c|c|c|c|c|}
\hline \multirow{4}{*}{ Perlakuan } & \multicolumn{6}{|c|}{ Lolos Saringan } & \multirow{4}{*}{$\begin{array}{l}\text { Spora } \\
\text { MVA }\end{array}$} \\
\hline & \multicolumn{2}{|c|}{$600 \mu \mathrm{m}$} & \multicolumn{2}{|c|}{$212 \mu \mathrm{m}$} & \multicolumn{2}{|c|}{$45 \mu \mathrm{m}$} & \\
\hline & \multicolumn{6}{|c|}{ Warna } & \\
\hline & Coklat & Putih & Coklat & Putih & Coklat & Putih & \\
\hline \multicolumn{8}{|c|}{ 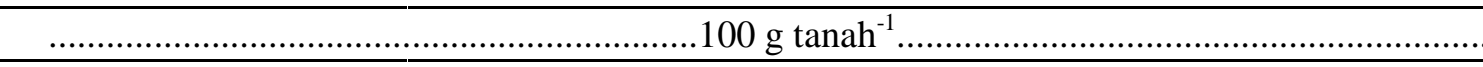 } \\
\hline $\mathrm{N}_{0} \mathrm{~T}_{1}$ & 5 & 1 & 153 & 182 & 332 & 293 & 242 \\
\hline $\mathrm{N}_{1} \mathrm{~T}_{1}$ & 3 & - & 136 & 157 & 329 & 283 & 227 \\
\hline $\mathrm{N}_{0} \mathrm{~T}_{2}$ & 6 & - & 179 & 163 & 391 & 259 & 250 \\
\hline $\mathrm{N}_{1} \mathrm{~T}_{2}$ & 2 & - & 117 & 152 & 276 & 367 & 229 \\
\hline $\mathrm{N}_{0} \mathrm{~T}_{3}$ & 1 & - & 169 & 174 & 342 & 286 & 243 \\
\hline $\mathrm{N}_{1} \mathrm{~T}_{3}$ & - & 1 & 142 & 154 & 275 & 244 & 204 \\
\hline
\end{tabular}

Keterangan : $\mathrm{T}_{1}=$ Olah Tanah Intensif, $\mathrm{T}_{2}=$ Olah Tanah Minimum, $\mathrm{T}_{3}=$ Tanpa Olah Tanah, $\mathrm{N}_{0}=$ Tanpa Pupuk N, $\mathrm{N}_{1}=$ Pupuk $\mathrm{N} 100 \mathrm{~kg} \mathrm{~N} \mathrm{ha}{ }^{-1}$. Sampel tanah diabil secara komposit dengan 6 perlakuan.

tumbuh dan berkembang pada kondisi yang kurang akan adanya unsur hara dan air. Sedangkan penambahan pupuk urea, akan menghambat perkembangan dan kolonisasi sehingga jumlah spora MVA yang dihasilkan berkurang. Hal ini sesuai dengan hasil penelitian Delvian (2008), bahwa pada perlakuan tanpa pemupukan urea mampu menghasilkan jumlah spora cukup tinggi. Sebaliknya, penambahan pupuk Urea mampu menurunkan jumlah spora Glomus margarita. Sehingga jumlah spora yang dihasilkan pada perlakuan penambahan pupuk $\mathrm{N}$ lebih rendah dibandingkan dengan tanpa pupuk $\mathrm{N}$.

Pada penelitian ini persen infeksi akar pada perlakuan sistem olah tanah berbeda nyata, sedangkan perlakuan pupuk $\mathrm{N}$ tidak berbeda nyata. Persen infeksi akar perlakuan $\mathrm{T}_{2}$ dan $\mathrm{T}_{3}$ lebih tinggi daripada $\mathrm{T}_{1}$ (Tabel
3). Hal ini diduga pada perlakuan $T_{2}$ dan $T_{3}$ mampu menciptakan kondisi lingkungan yang memungkinkan untuk perkembangan spora MVA dan meningkatkan kemampuan spora MVA untuk menginfeksi akar tanaman, sehingga infeksi akar tanaman padi gogo akan meningkat. Pada pengamatan ini persen infeksi akar terdapat vesikel didalam jaringan akar berbentuk bulat lonjong (Gambar 1C).

Bobot Kering Akar dan Bobot Berangkasan Kering Tanaman. Hasil pengamatan menunjukkan bahwa bobot kering akar dan bobot berangkasan kering tanaman perlakuan $\mathrm{N}_{1} \mathrm{~T}_{2}$ lebih tinggi dibandingkan dengan perlakuan lainnya dan perlakuan $\mathrm{N}_{0} \mathrm{~T}_{3}$ lebih rendah dibandingkan dengan perlakuan lainnya (Gambar 2). Hal ini disebabkan pada kombinasi $\mathrm{N}_{1} \mathrm{~T}_{2}$ permukaan tanah dikored sehingga bagian keras yang ada di 
permukaan tanah akan menjadi lebih rendah sehingga akar akan mampu mempenetrasi dan menyerap unsur hara dan gulma yang telah dikored akan dijadikan bahan organik tanah sehingga dapat di dekomposisi oleh mikroorganisme tanah. Selain itu penambahan pupuk N ke dalam tanah dapat digunakan oleh mikroorganisme tanah untuk melangsungkan proses dekomposisi sehingga dekomposisi berjalan cepat dan hasilnya dapat digunakan oleh tanaman untuk sebagai pupuk. Sehingga pada kombinasi perlakuan $\mathrm{N}_{1} \mathrm{~T}_{2}$ bobot berangkasan kering dan
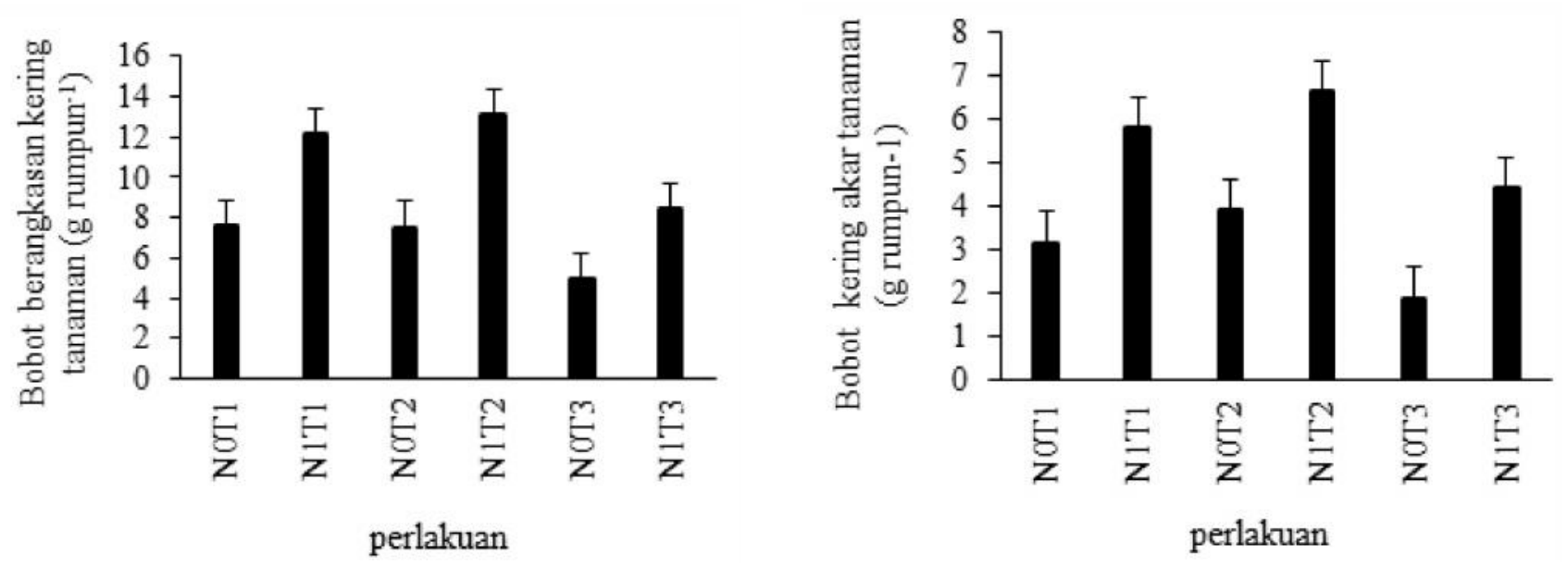

Gambar 2. Rerata data bobot berangkasan kering tanaman (A) dan bobot kering akar (B) pada masing-masing perlakuan sistem olah tanah dan pemupukan $\mathrm{N}$ (data tidak dapat dihomogenkan).

Tabel 3. Hasil uji BNT $5 \%$ rerata data jumlah spora MVA dan persen infeksi akar tanaman padi gogo pada fase vegetatif maksimum

\begin{tabular}{lll}
\hline Perlakuan & Jumlah Spora $\left(100 \mathrm{~g} \mathrm{tanah}^{-1}\right)$ & Persen Infeksi akar(\%) \\
\hline $\mathrm{T}_{1}$ & $235 \mathrm{a}$ & $38 \mathrm{a}$ \\
$\mathrm{T}_{2}$ & $240 \mathrm{a}$ & $57,5 \mathrm{~b}$ \\
$\mathrm{~T}_{3}$ & $224 \mathrm{a}$ & $63,7 \mathrm{~b}$ \\
\hline BNT 5\% & 29,02 & 16,8 \\
\hline $\mathrm{N}_{0}$ & $245 \mathrm{~b}$ & $54,3 \mathrm{a}$ \\
$\mathrm{N}_{1}$ & $220 \mathrm{a}$ & $51,5 \mathrm{a}$ \\
\hline BNT 5\% & 23,69 & 13,7 \\
\hline
\end{tabular}

Keterangan :Angka yang diikuti oleh huruf yang sama tidak berbeda menurut BNT pada taraf $5 \%$.

Tabel 4. Rerata data hasil analisis sifat kimia dan fisika tanah pada fase vegetatif maksimum pada tanaman padi gogo

\begin{tabular}{llllllll}
\hline \multirow{2}{*}{ Perlakuan } & \multicolumn{7}{c}{ Variabel Pengamatan } \\
\cline { 2 - 7 } & $\begin{array}{l}\mathrm{pH} \\
\left(\mathrm{H}_{2} \mathrm{O}\right)\end{array}$ & $\begin{array}{l}\text { Suhu } \\
\left({ }^{\mathrm{O}} \mathrm{C}\right)\end{array}$ & $\begin{array}{l}\text { Kadar Air } \\
(\%)\end{array}$ & $\begin{array}{l}\text { N-total } \\
(\%)\end{array}$ & $\begin{array}{l}\text { C-organik } \\
(\%)\end{array}$ & Ratio C/N & $\begin{array}{l}\text { P- tersedia } \\
(\mathrm{ppm})\end{array}$ \\
\hline $\mathrm{N}_{0} \mathrm{~T}_{1}$ & 5,45 & 32 & 55,30 & 0,16 & 1,90 & 11,88 & 5,89 \\
$\mathrm{~N}_{1} \mathrm{~T}_{1}$ & 5,21 & 31 & 53,17 & 0,17 & 2,06 & 12,12 & 5,48 \\
$\mathrm{~N}_{0} \mathrm{~T}_{2}$ & 5,81 & 30 & 63,13 & 0,21 & 1,84 & 8,76 & 4,29 \\
$\mathrm{~N}_{1} \mathrm{~T}_{2}$ & 5,27 & 31 & 64,08 & 0,14 & 1,61 & 4,36 & 3,97 \\
$\mathrm{~N}_{0} \mathrm{~T}_{3}$ & 5,55 & 31 & 67,30 & 0,17 & 1,99 & 11,71 & 4,84 \\
$\mathrm{~N}_{1} \mathrm{~T}_{3}$ & 5,35 & 31 & 70,61 & 0,24 & 1,83 & 7,63 & 3,93 \\
\hline
\end{tabular}

Keterangan: $\mathrm{T}_{1}=$ Olah Tanah Intensif, $\mathrm{T}_{2}=$ Olah Tanah Minimum, $\mathrm{T}_{3}=$ Tanpa Olah Tanah, $\mathrm{N}_{0}=$ Tanpa Pupuk N, $\mathrm{N}_{1}=$ Pupuk N $100 \mathrm{~kg} \mathrm{~N} \mathrm{ha}^{-1}$. Data diambil dari 24 sampel tanah, keculai analisis $\mathrm{P}$ tersedia hanya 6 sampel tanah (Komposit) 
Tabel 5. Rekapitulasi uji korelasi jumlah spora MVA dan persen infeksi akar tanaman padi gogo dengan C-organik, N-total, pH tanah, P-tersedia, Suhu Tanah, Kadar Air Tanah dan ratio C/ $\mathrm{N}$ pada fase vegetatif maksimum

\begin{tabular}{lcc}
\hline \multirow{2}{*}{ Variabel } & \multicolumn{2}{c}{ Nilai r } \\
\cline { 2 - 3 } & Jumlah Spora MVA & Persen Infeksi Akar \\
\cline { 2 - 3 } & Akhir & Akhir \\
\hline C-organik Tanah & $0,16 \mathrm{tn}$ & $-0,56 \mathrm{tn}$ \\
N-total Tanah & $-0,42 \mathrm{tn}$ & $0,26 \mathrm{tn}$ \\
pH Tanah & $0,26 \mathrm{tn}$ & $0,27 \mathrm{tn}$ \\
P-tersedia Tanah & $0,41 \mathrm{tn}$ & $-0,74 \mathrm{tn}$ \\
Suhu Tanah & $0,21 \mathrm{tn}$ & $-0,36 \mathrm{tn}$ \\
Kadar Air Tanah & $-0,23 \mathrm{tn}$ & $0,69 * *$ \\
Ratio C/N & $0,61 \mathrm{tn}$ & $-0,47 \mathrm{tn}$ \\
\hline
\end{tabular}

Keterangan: $(* *)=$ sangat nyata, $(\mathrm{tn})=$ tidak nyata. Analisis keseluruhan $(\mathrm{n}=24)$, analisis $\mathrm{N}, \mathrm{C}, \mathrm{C} / \mathrm{N}$ dan $P(n=6)$

Tabel 6. Rekapitulasi uji korelasi bobot kering akar, bobot berangkasan kering tanaman, dengan jumlah spora MVA dan persen infeksi akar pada tanaman padi gogo fase vegetatif maksimum

\begin{tabular}{llll}
\hline \multirow{2}{*}{ Variabel } & \multicolumn{2}{c}{ Nilai r } \\
\cline { 2 - 4 } & BKA & BBKT & Persen Infeksi Akar \\
\hline Jumlah spora MVA & 0,19 tn & 0,01 tn & 0,04 tn \\
Persen infeksi akar & 0,02 tn & $-0,22$ tn & \\
\hline
\end{tabular}

Keterangan: $(\operatorname{tn})=$ tidak nyata. $\mathrm{BKA}=$ bobot kering akar, $\mathrm{BBKT}=$ bobot berangkasan kering tanaman . $\mathrm{n}=24$

bobot kering akar tanaman lebih tinggi dibandingkan dengan kombinasi perlakuan lainnya.

Analisis Sifat Kimia dan Fisika Tanah pada Pertanaman Padi Gogo. Hasil analisis kimia dan fisika tanah pada fase vegetatif maksimum secara keseluruhan menunjukkan bahwa $\mathrm{pH}$ tanah pada masing-masing perlakuan berkisar antara 5,21 - 5,81,N-total berkisar antara 0,14-0,24\%, P-tersedia berkisar antara 3,93-5,89 ppm, C-organik tanah berkisar antara 1,61-2,06\% dan ratio $\mathrm{C} / \mathrm{N}$ berkisar antara 4,36-12,12. Selanjutnya untuk kadar air tanah berkisar antara 53,30-70,61\% dan suhu berkisar antara $30-31{ }^{\circ} \mathrm{C}$ (Tabel 4). Kondisi lingkungan dan sifat-sifat tanah tersebut masih cukup baik untuk perkembangan dan pertumbuhan MVA. Keberadaan MVA di dalam tanah dipengaruhi oleh $\mathrm{pH}$ tanah, kandungan hara yang rendah misalnya P-tersedia tanah yang rendah. Menurut Delvian (2008), kandungan Ptersedia tanah yang sangat rendah mampu meningkatkan jumlah spora MVA dibandingkan dengan P-tersedia yang tinggi malah akan mengurangi jumlah spora MVA.Berdasarkan penelitian Nurhalimah dkk., (2014) MVA mampu berkembang pada suhu $30^{\circ} \mathrm{C}$, tetapi untuk kolonisasi miselia berkisar $28^{\circ}-35^{\circ} \mathrm{C}$.
Korelasi Jumlah Spora dan Persen Infeksi Akar Mikoriza Vesikular Arbuskular dengan C-organik, N-total, pH tanah, P-tersedia, Suhu Tanah, Kadar Air Tanah dan Ratio C/N pada Fase Vegetatif Maksimum. Hasil uji korelasi menunjukkan bahwa pada pengamatan jumlah spora MVAdan persen infeksi akar tidak memiliki korelasi yang nyata terhadap sifat-sifat tanah baik kimia maupun fisika tanah, kecuali kadar air tanah berkorelasi positif dengan persen infeksi akar yaitu 0,69** (Tabel 5). Menurut Nurhalimah dkk., (2014), MVA akan berkembang pada kelembaban dan kadar air yang stabil, tidak terlalu tinggi dan tidak terlalu rendah. Namun pada kondisi kadar air berkisar antar 53,17-70,61\% masih cukup untuk MVA menginfeksi akar tanaman padi gogo. Menurut Manurung dkk., (2015) bahwa semakin rendah kadar air tanah maka persentase infeksi akar menurun, namun apabila kadar air tanah $>80 \%$ akan menghambat MVA untuk menginfeksi akar tanaman.

Korelasi Antara Bobot Kering Akar dan Bobot Berangkasan Kering Tanaman dengan Jumlah Spora MVA dan Infeksi Akar Serta Korelasi antara Jumlah Spora MVA dengan Infeksi Akar Tanaman Padi Gogo. Hasil uji korelasi menunjukkan bahwa pada pengamatan 
bobot kering akar dan bobot berangkasan kering tanaman tidak memiliki korelasi yang nyata terhadap jumlah spora dan infeksi akar MVA (Tabel 6). Hal ini diduga spora MVA belum mampu memperluas jangkauan hifa eksternal untuk menyerap baik unsur hara maupun air yang dibutuhkan oleh tanaman, sehingga bobot kering akar dan bobot berangkasan kering tanaman tidak meningkat. Selain itu tingkat kompatibilitas antara tanaman inang dengan jenis MVA di dalam tanah berbeda sehingga MVA belum mampu untuk meningkatkan serapan hara dan air serta faktor lingkungan yang berpengaruh terhadap perkembangan dan kolonisasi miselia fungi MVA. Menurut Nurhayati (2012), MVA tidak mempunyai spesifitas tertentu terhadap tanaman inang, namun kemampuan menginfeksi dan mengkoloni akar berbeda antar spesies yang satu dengan yang lainnya. Mikoriza asal rhizosfer tanaman inang yang sama dengan jenis tanaman inangnya lebih kompatibel daripada mikoriza asal rhizosfer tanaman inang yang berbeda dengan jenis tanaman inangnya. Jenis tanaman yang berbeda akan menunjukkan reaksi yang berlainan terhadap infeksi mikoriza dan secara tak langsung mempengaruhi perkembangan infeksi. Sedangkan pada penelitian ini menerapkan sistem rotasi tanaman serealialegum-bera ada kemungkinan daya adaptasi antara tanaman inang dan MVA yang terdapat pada lahan penelitian berbeda.

Pada uji korelasi antara jumlah spora MVA dan persen infeksi akar tanaman padi gogo tidak nyata. Hal ini menunjukkan bahwa persen infeksi akar tanaman tidak dipengaruhi oleh jumlah spora melainkan kemampuan MVA dalam menginfeksi tanaman itu berbeda-beda. Menurut Prihastuti (2010) tingkat infeksi akar oleh mikoriza yang terjadi tidak ditentukan oleh jumlah spora yang ada, tetapi lebih ditentukan oleh kemampuan mikoriza dan tanggap perakaran tanaman untuk berlangsungnya proses infeksi. Menurut Saputra dkk., (2015) tidak adanya hubungan yang searah antara jumlah spora dan infeksi akar.

\section{KESIMPULAN}

Kesimpulan dari penelitian ini adalah perlakuan olah tanah minimum dan tanpa olah tanah memiliki persen infeksi akar lebih tinggi dibandingkan dengan olah tanah intensif, tetapi tidak berbeda terhadap jumlah spora MVA. Perlakuan tanpa pemberian pupuk $\mathrm{N}$ memiliki jumlah spora MVA lebih tinggi dibandingkan dengan pemberian pupuk $\mathrm{N}$, tetapi tidak berbeda terhadap persen infeksi akar. Tidak terjadi interaksi antara sistem olah tanah dengan pemupukan $\mathrm{N}$ terhadap jumlah spora MVA dan persen infeksi akar. Tidak terjadi korelasi antara variabel utama dan variabel pendukung, kecuali persen infeksi dengan kadar air tanah.

\section{DAFTAR PUSTAKA}

Delvian. 2008. Pengaruh spesies inang dan sumber nutrisi terhadap produksi spora fungi mikoriza arbuskular. Jurnal Natur Indonesia. 10(2): 70-72.

Endriani. 2010. Sifat fisika dan kadar air tanah akibat penerapan olah tanah konservasi. Jurnal Hidrolitan. 1(1): 26-34.

Hakim, N., M. Yusuf N., A. M. Lubis., Sutopo G.H., M.Rusdi S., M. Amin D., Go Ban Hong, dan H. H. Bailey.1986. Dasar-dasar Ilmu Tanah. Lampung. $488 \mathrm{hlm}$.

Manurung Y.C., Asmarlaili S., Hanafiah, dan Posma M, 2015. Pengaruh berbagai kadar air tanah pada efektifitas mikoriza arbuskular terhadap pertumbuhan dan serapan hara bibit karet (Hevea brassiliensis Muell. Arg.) di rumah kaca. Jurnal Online Agroekoteknologi. 3(2): 465-475.

Marsono dan L. Pinus. 2001. Petunjuk Penggunaan Pupuk. Penebar Swadaya. Jakarta. $150 \mathrm{hlm}$.

Nurhalimah, S. Sri N, dan Anton M. 2014. Eksplorasi Mikoriza Vesikular Arbuskular (MVA) Indigenous pada Tanah Regosol di Pamekasan, Madura. Jurnal Sains dan Seni Pomits. 3(1): 30-35.

Nurhayati. 2012. Mycorrizhal infectiveness in types of host plants and source of inoculum. Jurnal. Floratek. 7: 25-31.

Prihastuti, Sudaryono, dan E. Handayanto. 2010. Keanekaragaman jenis mikoriza vesikular arbuskular dan potensinya dalam pengelolaan kesuburan lahan ultisol. Seminar Nasional Biologi, Yogyakarta, hlm: 76-85.

Saputra, H., Rizalinda, dan Irwan L. 2015. Jamur mikoriza vesikular arbuskular (MVA) pada perakaran tanaman bawang merah (Eleutherine americana Merr.). Jurnal Protobiont. 4(1): 143-150.

Simanungkalit, R.D.M., D. A. Suriadikarta, R. Saraswati, D. Setyorini, dan W. Hartatik. 2006. Pupuk Organik dan Pupuk Hayati (Organic Fertil- 
izer And Biofertilizer). Balai Besar Penelitian dan Pengembangan Sumberdaya Lahan Pertanian. Jawa Barat. 313 hlm.

Utomo, M. 2012. Tanpa Olah Tanah: Teknologi Pengolahan Pertanian Lahan Kering. Lembaga Penelitian Universitas Lampung. Bandar Lampung. $110 \mathrm{hlm}$.
Yusnaini, S., S.G. Nugroho., M.A.S. Arif, A. Niswa- ti, Dermiyati. 2012. Penuntun Praktikum Teknologi Pengelolaan Agen Biologis Hara. Fakultas Pertanian. Universitas Lampung. Lampung. 42 hlm. 